\title{
Ecological analysis of heavy metal and radioactivity potential of Holocene sediments in Iznik Lake
}

Zeki U. Yumun, Erol Kam

\begin{abstract}
In this study, the heavy metal and radioactive properties of Iznik Lake were investigated. Concentration values of the first ( $\mathrm{Ag}, \mathrm{Bi}, \mathrm{Mo}, \mathrm{Sn}, \mathrm{Se}, \mathrm{Zn}, \mathrm{As}, \mathrm{B}, \mathrm{Cd}, \mathrm{Co}, \mathrm{Cr}, \mathrm{Cu}, \mathrm{Ni}, \mathrm{Pb}, \mathrm{Pt}$ and $\mathrm{Sb}$ ) and second ( $\mathrm{Na}, \mathrm{Mg}$, $\mathrm{K}, \mathrm{Ca}, \mathrm{P}, \mathrm{S}, \mathrm{Fe}, \mathrm{Al}$ and $\mathrm{Mn}$ ) group of elements in borehole $1(\mathrm{BH}-1)$ drilling did not show much variation from the top to the bottom of the drilling. Concentration values of the first group of elements in borehole $2(\mathrm{BH}-2)$ drill samples decreased at higher levels of drilling. In addition, natural and anthropogenic radionuclides were measured by gamma spectrometry, and the results of environmental natural radioactivity of Iznik Lake and its surroundings were determined. In the measurement results, Ra-226 was found to be below the world average value at all locations. It is assumed that the determination of K-40 values above the average values was due to agricultural activities carried out intensively in the study area. Th-232 values were found to be below the world average value in drilling samples; Cs-137 values were below the background level in all samples. According to these results, the study area does not contain any unnatural radioactivity.
\end{abstract}

Keywords: Iznik Lake $\bullet$ heavy metals $\bullet$ radionuclides $\bullet$ geochemical analyses $\bullet$ radionuclide determination

\section{Z. U. Yumun}

Çorlu Engineering Faculty

Namik Kemal University

Tekirdag, Turkey

\section{E. $\operatorname{Kam}^{凶}$}

Department of Physics

Faculty of Sciences

Yıldız Technical University

Esenler, Istanbul, Turkey

E-mail: erolkam@yildiz.edu.tr

Received: 19 June 2018

Accepted: 20 March 2019

\section{Introduction}

The study area, Iznik Lake, is a fresh water lake located in the town of Iznik in Bursa Province in the Marmara region. The region's largest, and fifth largest in all of Turkey, natural Iznik Lake was formed tectonically. Iznik Lake has a surface area of $310 \mathrm{~km}^{2}$, a length of $33 \mathrm{~km}$, a width of $12 \mathrm{~km}$ and an average depth of $30 \mathrm{~m}$. As one moves away from the shores of the lake, the depth increases rapidly [1]. The Iznik Lake basin is located in the important agricultural production centre of the southern Marmara region, with suitable climate and soil characteristics as well as irrigation facilities. The lake, which is an important water source for the agricultural and industrial activities in the basin, has a very important position not only for the water supply but also for water sports and resort facilities [2]. The lake contains climatic and geological archival features within its sediments. There have been three low lake levels that have influenced the sedimentation conditions of Iznik Lake. The first is related to the Last Glacial Maximum, and the second is associated with the Younger Dryas period, which also led to the formation of the iron sulphide layer in the sediment. The third low lake level occurred at the same time as the ash level AP2 (today's $3.5 \mathrm{cal} \mathrm{ky),}$ which was transported from the middle of Iznik Lake to the lower basin [3]. 


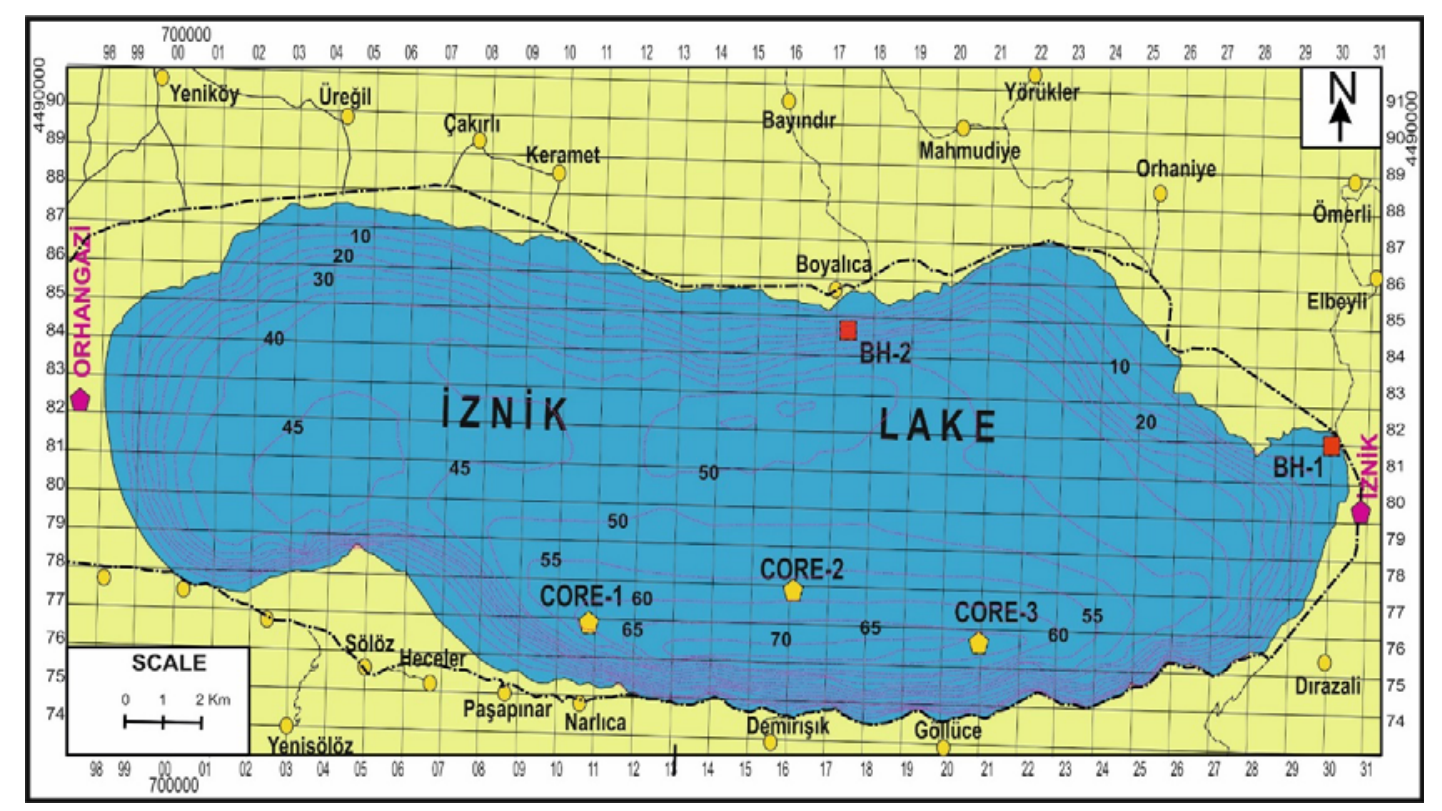

Fig. 1. Study area and sample locations [9].

Iznik Lake is heavily polluted by settlements and industrial establishments on the shores. Among the pollutants are heavy metals and radioactive pollutants. The radionuclides found in natural rocks, nuclear tests, accidents and leaks from nuclear power plants generate radioactive pollution; industrial discharges and atmospheric sedimentation events also increase heavy metal pollution [4]. The amounts of radionuclides, such as U-238, Th-232 and K-40, which are natural radionuclides, found in the soil are connected to the rock cementite, which is the origin of the soil. High radiation levels are seen in volcanic rocks such as granite, phosphate and salt rocks, and low radiation levels are seen in sedimentary rocks [5]. Anthropogenic radionuclides, such as Cs-137, are spread by nuclear flares, accidents and leaks from nuclear power plants [6]. Discharges from industries create radioactive pollution in the lake environment as well as heavy metal pollution. In addition, the excessive use of fertilizers and pesticides, as a result of agricultural activities, increases the accumulation of heavy metals in lake water and sediments. Various scientific studies have been conducted in the region in recent years [1-3, 7, 8]. Basar et al. [2] determined the heavy metal contents of agricultural soils that were irrigated with various water sources in the Iznik Lake basin. Meric et al. [1] investigated the existence of a possible connection between Iznik Lake and Gemlik Gulf using contemporary fossils. Basar et al. [7] investigated the contamination of lake water and soils polluted with industrial and domestic wastes. Heavy metal measurements were made in plants that were continuously watered with lake water.

According to Viehberg et al. [3], paleoenvironmental factors in the Late Pleistocene and Holocene periods have been investigated using lake sediments bearing the climatic and geological records characteristic of Iznik Lake.

Sagular et al. [8] investigated the Iznik (northwest Turkey) Quaternary Era, using the fossil record of spicule acids and nannofossil chrono biostratigraphy, based on detailed historical and paleoenvironmental characteristics. Meric et al. [9] investigated the connection between Gemlik Gulf and Iznik Lake.

In this study, heavy metal and radioactive pollution of Iznik Lake was investigated. In addition, natural and artificial radionuclides were measured by gamma ray spectrometry, and the results of environmental natural radioactivity of Iznik Lake and its surroundings were determined.

\section{Materials and methods}

A total of $46 \mathrm{~m}$ core samples and three core samples (Core 1, Core 2 and Core 3) were collected from two drillings (borehole 1 [BH-1] = $18 \mathrm{~m}$ and borehole 2 $[\mathrm{BH}-2]=28 \mathrm{~m}$ ) made at Iznik Lake. The location of the study area and sample points are shown in Fig. 1. For geochemical analyses, the samples were first ground. Geochemical analyses of ground samples (Fe, Zn, Al, Mn, As, B, Cd, Co, Cr, Cu, Ni, $\mathrm{Na}, \mathrm{Mg}, \mathrm{K}, \mathrm{Ca}, \mathrm{P}$ and $\mathrm{Bi}, \mathrm{Mo}, \mathrm{Pb}, \mathrm{Pt}, \mathrm{Sb}, \mathrm{Sn}, \mathrm{Se}, \mathrm{Hg}$ ) were carried out by using SPECTROBLUE model ICP-OES instrument at the Namik Kemal University Central Research Laboratory (NABILTEM).

In addition, the results of environmental natural radioactivity of Iznik Lake and its surroundings were determined by gamma spectrometry (Table 1). For the radionuclide analysis, samples were initially stored at room temperature in a laboratory environment prior to radioactive analysis. Analyses of the prepared samples were carried out in the Cekmece Radioactivity and Analytical Measurement section. The samples were finely pulverized by passing through a $100-\mu \mathrm{m}$ sieve. The powdered samples were placed in 1000-ml Marinelli test bottles, and holes of bottles were closed to prevent air contact. The samples were allowed to equilibrate with radium, thorium and other degradation products for 40 days after weighing [10]. Sediment analysis 
Table 1. Measurement results of BH-1 and BH-2 and Core 1, Core 2 and Core 3 locations

\begin{tabular}{|c|c|c|c|c|c|c|c|}
\hline Sample no. & $\begin{array}{c}\mathrm{K}-40 \\
{[\mathrm{~Bq} / \mathrm{kg}]}\end{array}$ & $\begin{array}{l}\text { The uncertainty } \\
\text { of the } \\
\text { measurement } \\
{[\mathrm{Bq} / \mathrm{kg}]}\end{array}$ & $\begin{array}{c}\text { Th-232 } \\
{[\mathrm{Bq} / \mathrm{kg}]}\end{array}$ & $\begin{array}{c}\text { The uncertainty } \\
\text { of the } \\
\text { measurement } \\
{[\mathrm{Bq} / \mathrm{kg}]}\end{array}$ & $\begin{array}{l}\mathrm{Ra}-226 \\
{[\mathrm{~Bq} / \mathrm{kg}]}\end{array}$ & $\begin{array}{l}\text { The uncertainty } \\
\text { of the } \\
\text { measurement } \\
{[\mathrm{Bq} / \mathrm{kg}]}\end{array}$ & $\begin{array}{c}\text { Cs-137 } \\
{[\mathrm{Bq} / \mathrm{kg}]}\end{array}$ \\
\hline$\overline{\mathrm{BH}}-1 / 1$ (Boyalica) & 181 & \pm 13.45 & 18.55 & \pm 4.30 & Background & & Background \\
\hline BH-1/2 (Boyalica) & 323 & \pm 17.97 & 27.93 & \pm 5.28 & 30.35 & \pm 5.50 & Background \\
\hline BH-1/3 (Boyalica) & 402 & \pm 20.04 & 39.36 & \pm 6.27 & 14.99 & \pm 3.87 & Background \\
\hline Average & 302 & & 28.61 & & 22.67 & & Background \\
\hline $\mathrm{BH}-2 / 1$ & 339 & \pm 18.41 & 38.30 & \pm 6.16 & 13.92 & \pm 3.72 & Background \\
\hline $\mathrm{BH}-2 / 2$ & 505 & \pm 22.47 & 50.00 & \pm 2.47 & 29.94 & \pm 5.46 & Background \\
\hline $\mathrm{BH}-2 / 3$ & 364 & \pm 19.07 & 30.34 & \pm 5.47 & 19.34 & \pm 4.36 & Background \\
\hline Average & 403 & & 39.50 & & 21.00 & & Background \\
\hline
\end{tabular}

was performed using the gamma ray spectrometer Canberra GX5020 coupled with a coaxial HPGe detector $(50 \%$ efficiency and $2.0 \mathrm{keV}$ resolution for the $1332.5 \mathrm{keV} \gamma$-ray line of ${ }^{60} \mathrm{Co}$ ).

In this method, radionuclides that emit gamma rays at an energy range of $40 \mathrm{keV}$ to $2000 \mathrm{keV}$ present in the sample matrix (many environmental and biological specimens such as air, water, soil, sediments, plants, vegetables and animal foods) are determined by direct gamma spectrometry. Gamma spectrometry is the technique most commonly used to identify gamma rays emitting radioisotopes in various radioactive samples [11-13].

Iznik Lake is a cliched-clastic lake. The coastal sediments are coarse grained deltaic sand and conglomerates. The north coast contains a small amount of sand silt. Some sections are rocky. The incoming materials may be due to river or coastal erosion. As the depth increases, sedimentation slows down, and the silt-clay-sized material is stored. The sediments are crushed and reflect the combination of the main sediments [14]. It is estimated that since the Late Pleistocene in the Iznik Lake area, a vertical displacement of $100 \mathrm{~m}$ has taken place as a result of the tectonic movements of the lake [9].

\section{Findings and results}

The drilling in the study area and vertical sections of the cores are shown in Figs. 2a and 2b. According to the sections, the drilling of $\mathrm{BH}-1$ descends to a depth of $30 \mathrm{~m}$ from the surface of the lake. The water depth is $9 \mathrm{~m}$, and there is greenish-grey clay
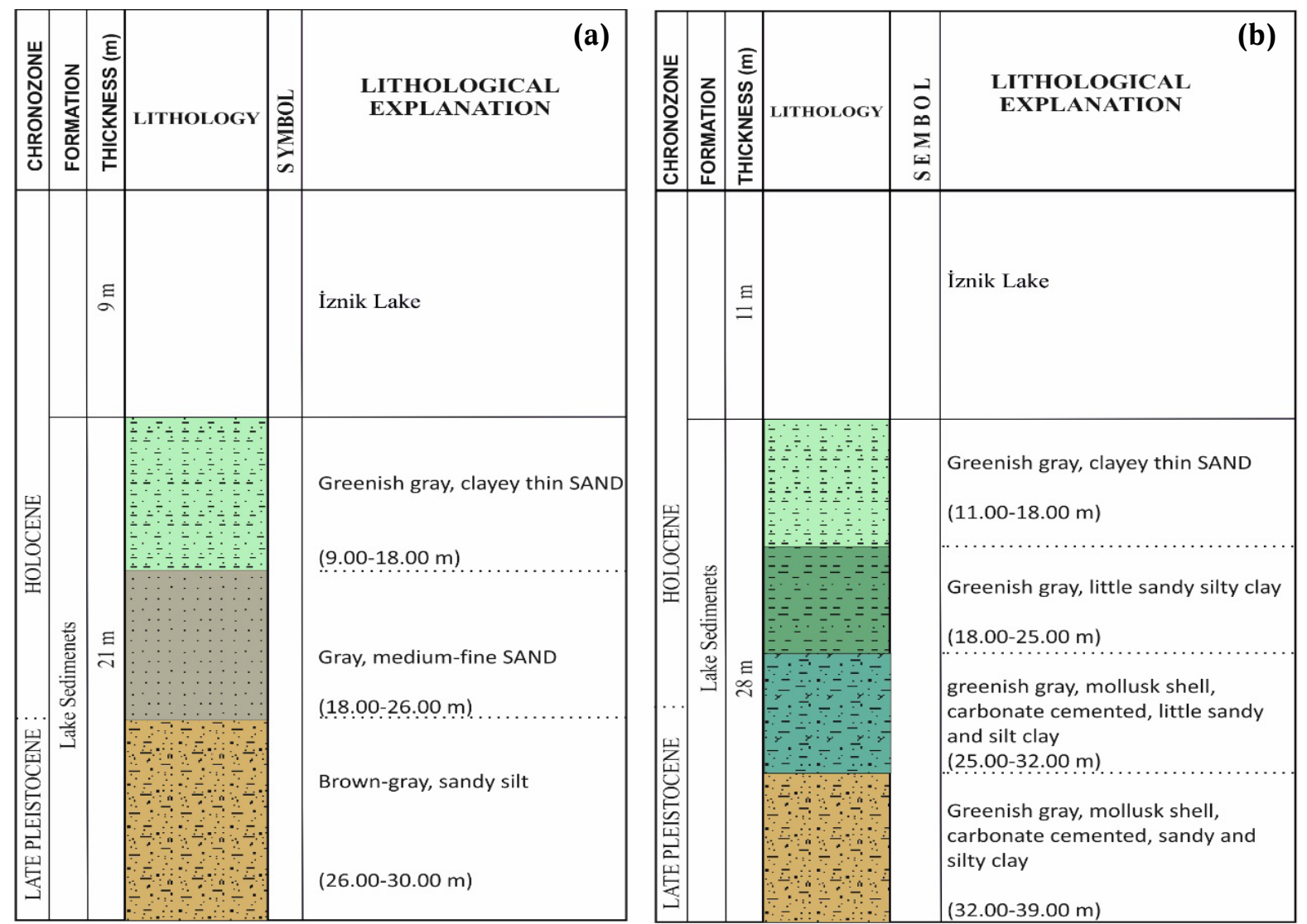

Fig. 2. Vertical section of BH-1 drilling (a) and BH-2 drilling (b). 
- fine-grained sand with a thickness of $9 \mathrm{~m}$ from the bottom of the lake. Beneath this level is grey, medium, fine-grained sand. More deeply, there is a brown-grey sandy silt clay (Fig. 2a). BH-2 drilling is made up to $39 \mathrm{~m}$ deep from the lake's surface where the water depth is $11 \mathrm{~m}$. Beginning from the water base, there is greenish-grey clay-fine-grained sand between 11 and $18 \mathrm{~m}$. Between 18 and $25 \mathrm{~m}$, there is greenish-grey coloured, slightly sandy, silty clay.

Below this, between 25-32 m, there are greenish-grey silty clay, less sandy and silty clay with mollusc shells and carbonate cemented. From 32 to 39 m, there are with a greenish-grey coloured, mollusc shells and carbonate cemented sand and silty clay. Vertical sections of the core specimens are given in Figs. 3a-3c.

In Core 1, the water depth is $60 \mathrm{~m}$ and the sample size is $70 \mathrm{~cm}$. The sample is a green silvery grey, silty silk with high water content and little fine sand. In the Core 2 location, the water depth is $65 \mathrm{~m}$ and the sample size is $90 \mathrm{~cm}$. The sedimentary greenish-grey, water-rich siltstone containing fine sand was taken from Core 2. In the Core 3 location, the water depth is $70 \mathrm{~m}$ and the sample size is $90 \mathrm{~cm}$. Blackish-grey silty clay is found in the sediment; bitumen is a significant component.

The results of the radioactivity measurements of sediment samples from the locations are given in Table 1, and the world mean values in rocks are given in Table 2. According to the measurement results, the average Ra-226 value of the drilling samples was highest at $\mathrm{BH}-1(22.67 \mathrm{~Bq} / \mathrm{kg})$. This value is
Table 2. Important natural radionuclides and average specific activities in soil [4]

\begin{tabular}{lc}
\hline \multicolumn{1}{c}{ Radionuclides } & Activity [Bq/kg] \\
\hline Uranium-238 & 33 \\
Thorium-232 & 45 \\
Potassium-40 & 420 \\
Radium-226 & 32 \\
\hline
\end{tabular}

below the world average $(32 \mathrm{~Bq} / \mathrm{kg})$. The $\mathrm{K}-40$ value was the highest at $\mathrm{BH}-2 / 2(505 \mathrm{~Bq} / \mathrm{kg})$. This value is above the world average $(420 \mathrm{~Bq} / \mathrm{kg})$. Thorium-232 values were found to be below the world average value in the drilling samples (highest value was at $\mathrm{BH}-1 / 3(39.36 \mathrm{~Bq} / \mathrm{kg}))$.

In the case of the core samples, the Ra-226 value was found to be highest at the Kapakli location $(31.22 \mathrm{~Bq} / \mathrm{kg})$, which is below the world average value. The highest values for the Th-232 and K-40 were found to be at the Kursunlu location (Th-232: $44.93 \mathrm{~Bq} / \mathrm{kg}$ and $\mathrm{K}-40: 498 \mathrm{~Bq} / \mathrm{kg}$ ), which are above the world averages. Cesium-137 values were below the background level in both drilling and core samples.

According to these results, the study area does not contain any unnatural radioactivity. The determination of K- 40 values above the world average at all locations is presumed to be due to agricultural activities in the study area. Because of anthropogenic pollution, natural radionuclides appear to be increased in sediments.

The results of the geochemical analyses are given in Tables 3, 4, 5 and 6. According to the results of

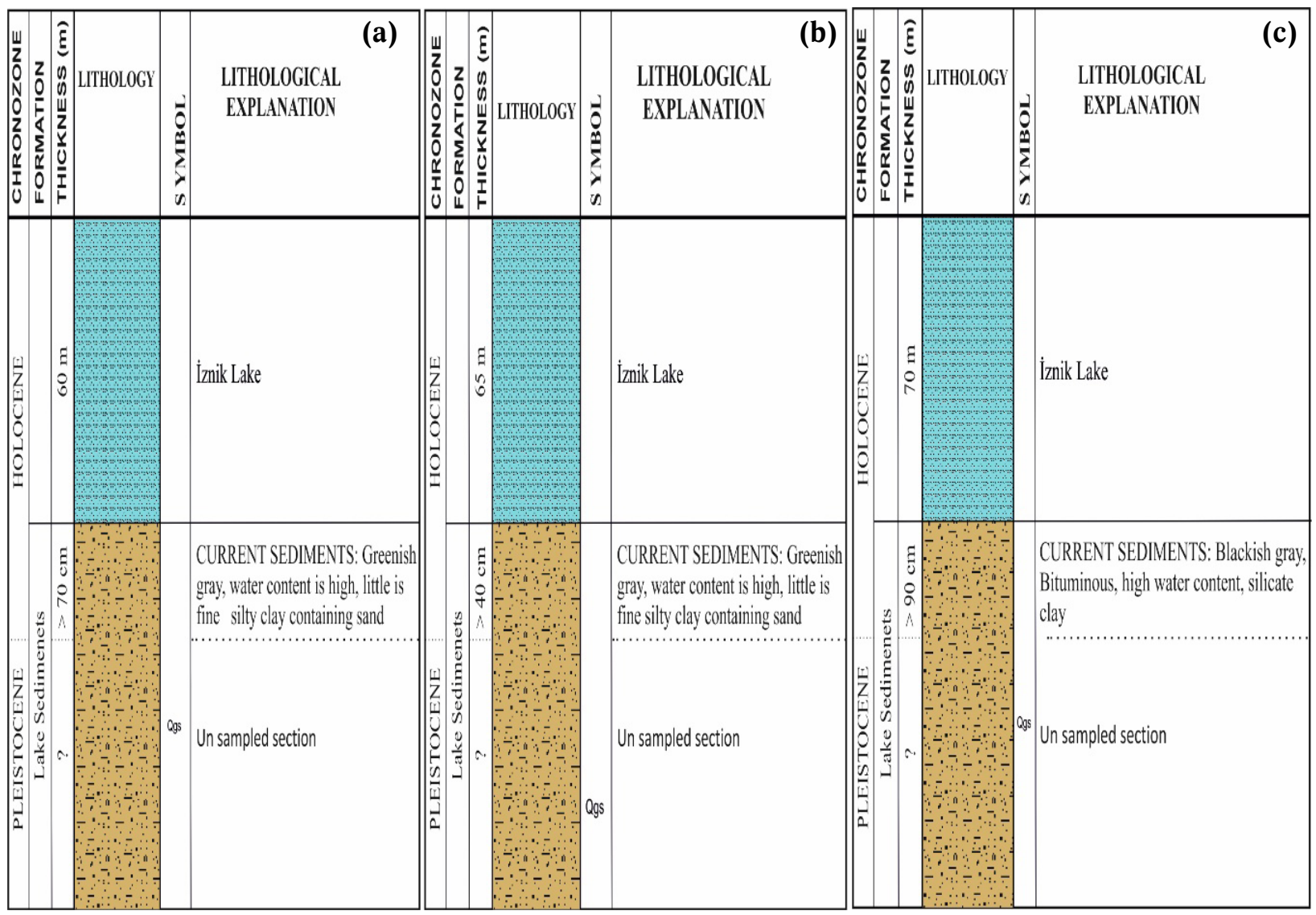

Fig. 3. Vertical section of Core 1 (a), Core 2 (b) and Core 3 (c). 
Table 3. Geochemical analysis results of Group 1 elements of BH-1 drilling ('IZ' is the abbreviation of Iznik, which is the name of an investigation area)

\begin{tabular}{|c|c|c|c|c|c|c|c|c|c|c|c|}
\hline SK-1 & $\mathrm{Zn}$ & As & B & $\mathrm{Cd}$ & Co & $\mathrm{Cr}$ & $\mathrm{Cu}$ & $\mathrm{Ni}$ & $\mathrm{Pb}$ & $\mathrm{Pt}$ & $\mathrm{Sb}$ \\
\hline$\overline{\text { IZ-1/9-10 }}$ & 34.67 & 3.16 & 6.01 & 0.41 & 13.21 & 14.73 & 17.34 & 26.20 & 0.00 & 0.31 & 0.69 \\
\hline IZ-1/10-11 & 37.06 & 0.73 & 7.41 & 0.35 & 15.33 & 21.46 & 25.92 & 33.65 & 0.00 & 0.18 & 0.57 \\
\hline IZ-1/11-12 & 40.50 & 0.00 & 7.79 & 0.47 & 15.90 & 24.00 & 29.13 & 38.26 & 0.00 & 0.25 & 0.56 \\
\hline IZ-1/12-13 & 40.37 & 2.30 & 10.27 & 0.31 & 15.90 & 27.97 & 29.11 & 40.28 & 0.00 & 0.00 & 0.79 \\
\hline IZ-1/13-14 & 38.08 & 2.76 & 7.89 & 0.63 & 16.05 & 18.60 & 20.21 & 30.09 & 0.00 & 0.52 & 0.70 \\
\hline IZ-1/14-15 & 40.53 & 2.87 & 7.81 & 0.59 & 17.57 & 23.85 & 26.58 & 37.63 & 3.81 & 0.46 & 0.63 \\
\hline IZ-1/15-16 & 34.46 & 3.22 & 9.22 & 0.14 & 14.51 & 21.86 & 20.44 & 31.68 & 0.00 & 0.00 & 0.72 \\
\hline IZ-1/16-17 & 41.08 & 2.82 & 13.24 & 0.36 & 16.25 & 24.33 & 24.65 & 36.47 & 0.00 & 0.18 & 1.26 \\
\hline IZ-1/17-18 & 38.06 & 5.73 & 8.77 & 0.66 & 14.77 & 20.72 & 16.67 & 32.60 & 0.00 & 0.56 & 0.65 \\
\hline IZ-1/18-19 & 27.53 & 4.09 & 5.01 & 0.35 & 11.39 & 11.47 & 7.90 & 16.90 & 0.00 & 0.24 & 0.23 \\
\hline IZ-1/19-20 & 40.52 & 3.85 & 4.50 & 0.73 & 11.20 & 11.35 & 9.86 & 16.68 & 0.00 & 0.70 & 0.30 \\
\hline IZ-1/20-21 & 61.50 & 4.08 & 4.95 & 0.64 & 11.53 & 16.40 & 8.82 & 18.10 & 0.00 & 0.58 & 0.02 \\
\hline IZ-1/21-22 & 29.26 & 7.42 & 5.86 & 0.52 & 11.13 & 9.21 & 5.72 & 13.80 & 0.00 & 0.43 & 0.26 \\
\hline
\end{tabular}

Table 4. Geochemical analysis results of Group 2 elements of BH-1 drilling ('IZ' is the abbreviation of Iznik, which is the name of an investigation area)

\begin{tabular}{cccccccccc}
\hline \multicolumn{1}{c}{$\mathrm{SK}-1$} & $\mathrm{Na}$ & $\mathrm{Mg}$ & \multicolumn{1}{c}{$\mathrm{K}$} & $\mathrm{Ca}$ & $\mathrm{P}$ & $\mathrm{S}$ & $\mathrm{Fe}$ & $\mathrm{Al}$ & $\mathrm{Mn}$ \\
\hline $\mathrm{IZ}-1 / 9-10$ & 552.3 & 4916.9 & 936.1 & 23183.5 & 251.0 & 529.4 & 21724.6 & 9593.4 & 569.0 \\
$\mathrm{IZ}-1 / 10-11$ & 666.8 & 6204.5 & 1626.3 & 19569.1 & 299.0 & 308.8 & 27420.3 & 13068.6 & 682.1 \\
$\mathrm{IZ}-1 / 11-12$ & 673.0 & 6650.3 & 1745.5 & 16911.6 & 314.8 & 223.1 & 29324.1 & 13423.9 & 774.1 \\
IZ-1/12-13 & 699.9 & 6831.4 & 2507.4 & 14385.1 & 296.4 & 214.9 & 27703.0 & 15371.3 & 709.2 \\
IZ-1/13-14 & 655.3 & 6056.8 & 1420.0 & 27529.8 & 292.8 & 588.6 & 26584.8 & 11267.9 & 670.9 \\
IZ-1/14-15 & 729.4 & 6391.1 & 1768.7 & 20347.9 & 306.1 & 405.8 & 29940.3 & 12775.6 & 770.5 \\
IZ-1/15-16 & 646.4 & 6747.2 & 1725.5 & 20980.2 & 254.2 & 810.2 & 23422.8 & 12061.0 & 672.6 \\
IZ-1/16-17 & 575.5 & 7908.1 & 2446.8 & 19214.2 & 263.3 & 745.2 & 27415.8 & 13655.0 & 856.9 \\
IZ-1/17-18 & 570.0 & 8771.6 & 1831.4 & 40692.6 & 316.6 & 729.2 & 26809.2 & 10783.1 & 759.7 \\
IZ-1/18-19 & 719.0 & 5809.8 & 1350.1 & 60840.4 & 232.3 & 270.2 & 19331.5 & 8307.6 & 652.7 \\
IZ-1/19-20 & 710.1 & 6027.8 & 814.7 & 72157.4 & 260.9 & 422.1 & 22132.1 & 6323.3 & 743.2 \\
IZ-1/20-21 & 708.0 & 5920.4 & 1064.2 & 69235.8 & 244.4 & 418.7 & 21724.2 & 6859.7 & 652.8 \\
IZ-1/21-22 & 874.2 & 6570.5 & 1212.8 & 10814.6 & 255.2 & 957.6 & 20910.3 & 7527.9 & 866.8 \\
\hline
\end{tabular}

analysis, $\mathrm{Ag}, \mathrm{Bi}, \mathrm{Mo}$, Sn and Se concentrations were below the measurement limit values in all samples. The concentration values of the elements $\mathrm{Zn}, \mathrm{As}, \mathrm{B}$, $\mathrm{Cd}, \mathrm{Co}, \mathrm{Cr}, \mathrm{Cu}, \mathrm{Ni}, \mathrm{Pb}, \mathrm{Pt}$ and $\mathrm{Sb}$ were $0-100 \mathrm{ppm}$; these elements were defined as the first-group elements. Concentration values of $\mathrm{Na}, \mathrm{Mg}, \mathrm{K}, \mathrm{Ca}, \mathrm{P}$, $\mathrm{S}, \mathrm{Fe}, \mathrm{Al}$ and $\mathrm{Mn}$ elements were determined to be $>100 \mathrm{ppm}$, and these elements were considered as the second-group elements.

Concentration values of the first- and second-group elements in the $\mathrm{BH}-1$ sounding show little variation from the upper level to the lower level of the drilling. Concentration values of the first-group elements in BH-2 sounding samples were observed to decrease more deeply at the top of drilling. In the area where the drilling of $\mathrm{BH}-2$ is located, there are extensive agricultural activities and urban settlements in the coastal areas. The primary responsibility for this heavy metal contamination is thus agricultural activity and urban settlement.

\section{Conclusion}

The average values of the radionuclide analyses were examined. In BH-1 drilling, K-40: $302 \mathrm{~Bq} / \mathrm{kg}$, Th-232: $28.61 \mathrm{~Bq} / \mathrm{kg}, \mathrm{Ra}-226: 22.67 \mathrm{~Bq} / \mathrm{kg}$ and
Cs-137: backgrounds were determined. In $\mathrm{BH}-2$ drilling, K-40: $403 \mathrm{~Bq} / \mathrm{kg}$, Th-232: $39.5 \mathrm{~Bq} / \mathrm{kg}$, Ra-226: $21 \mathrm{~Bq} / \mathrm{kg}$ and Cs-137: backgrounds were determined. These values were compared with those of the important natural radionuclides and average specific activities found in the soil. The values obtained in this study are below the world standard values.

BH-2 data are assumed to be higher than $\mathrm{BH}-1$ data due to pesticides and fertilizers used in agricultural activities.

Specific activity values obtained in this study have been correlated with the values of United Nations Scientific Committee on the Effects of Atomic Radiation (UNESCAR) in Table 2. According to geochemical analysis results, $\mathrm{Ag}, \mathrm{Bi}, \mathrm{Mo}, \mathrm{Sn}$ and Se concentrations are below the measurement limit values in all samples. In this study, the concentration values of elements $\mathrm{Zn}, \mathrm{As}, \mathrm{B}, \mathrm{Cd}, \mathrm{Co}, \mathrm{Cr}, \mathrm{Cu}, \mathrm{Ni}, \mathrm{Pb}$, $\mathrm{Pt}$ and $\mathrm{Sb}$ are in the range of $0-100 \mathrm{ppm}$, and it is understood that the first-group elements originate from natural rocks and agricultural activities. The elements of the second group, $\mathrm{Na}, \mathrm{Mg}, \mathrm{K}, \mathrm{Ca}, \mathrm{P}, \mathrm{S}$, $\mathrm{Fe}, \mathrm{Al}$ and $\mathrm{Mn}$, were determined to be $>100 \mathrm{ppm}$, and the excess of these elements was mostly thought to occur from the surrounding rocks. 
Table 5. Geochemical analysis results of Group 1 elements of BH-2 drilling ('IZ' is the abbreviation of Iznik, which is the name of an investigation area)

\begin{tabular}{|c|c|c|c|c|c|c|c|c|c|c|c|}
\hline SK-2 & $\mathrm{Zn}$ & As & B & $\mathrm{Cd}$ & Co & $\mathrm{Cr}$ & $\mathrm{Cu}$ & $\mathrm{Ni}$ & $\mathrm{Pb}$ & $\mathrm{Pt}$ & $\mathrm{Sb}$ \\
\hline IZ-2/11-12 & 54.48 & 5.45 & 13.71 & 0.73 & 18.24 & 54.19 & 28.57 & 60.42 & 4.62 & 0.63 & 0.52 \\
\hline IZ-2/12-13 & 37.98 & 1.48 & 13.39 & 0.72 & 17.60 & 64.93 & 35.39 & 70.00 & 4.58 & 0.61 & 0.49 \\
\hline IZ-2/13-14 & 35.75 & 8.01 & 15.65 & 0.38 & 15.56 & 51.88 & 26.05 & 58.93 & 3.34 & 0.22 & 0.09 \\
\hline IZ-2/14-15 & 48.42 & 8.98 & 27.54 & 0.62 & 22.24 & 93.34 & 34.88 & 111.53 & 6.71 & 0.13 & 0.52 \\
\hline IZ-2/15-16 & 44.57 & 12.29 & 22.56 & 0.40 & 17.61 & 78.60 & 32.07 & 88.75 & 8.22 & 0.00 & 0.14 \\
\hline IZ-2/16-17 & 46.87 & 10.15 & 19.29 & 0.71 & 18.26 & 80.32 & 40.79 & 93.32 & 7.10 & 0.45 & 0.00 \\
\hline IZ-2/17-18 & 65.18 & 6.94 & 21.93 & 1.03 & 23.40 & 99.49 & 61.90 & 122.12 & 5.30 & 0.48 & 0.00 \\
\hline IZ-2/18-19 & 45.66 & 6.79 & 25.25 & 0.19 & 17.41 & 80.58 & 38.35 & 95.95 & 7.13 & 0.00 & 0.13 \\
\hline IZ-2/19-20 & 50.89 & 2.10 & 30.46 & 0.43 & 18.49 & 88.61 & 38.84 & 107.81 & 6.60 & 0.00 & 0.00 \\
\hline IZ-2/20-21 & 58.30 & 4.34 & 27.63 & 0.00 & 19.72 & 99.67 & 48.55 & 115.33 & 7.90 & 0.00 & 0.53 \\
\hline IZ-2/21-22 & 54.05 & 0.00 & 25.25 & 0.29 & 18.42 & 88.63 & 37.63 & 108.02 & 6.41 & 0.00 & 0.39 \\
\hline IZ-2/22-23 & 58.89 & 1.98 & 23.18 & 0.00 & 18.66 & 89.85 & 44.15 & 111.22 & 8.12 & 0.00 & 0.13 \\
\hline IZ-2/23-24 & 57.52 & 8.31 & 40.26 & 0.37 & 24.30 & 114.32 & 46.73 & 149.48 & 4.95 & 0.00 & 0.24 \\
\hline IZ-2/24-25 & 57.90 & 6.05 & 33.27 & 0.27 & 21.96 & 95.30 & 44.12 & 118.99 & 7.31 & 0.00 & 0.34 \\
\hline IZ-2/25-26 & 57.52 & 8.07 & 36.75 & 0.85 & 23.10 & 109.65 & 46.22 & 145.77 & 3.93 & 0.36 & 0.43 \\
\hline IZ-2/26-27 & 59.59 & 6.17 & 33.70 & 0.51 & 19.64 & 84.94 & 42.36 & 103.09 & 5.03 & 0.00 & 0.19 \\
\hline IZ-2/27-28 & 65.90 & 8.65 & 37.14 & 0.77 & 22.05 & 91.94 & 43.70 & 117.43 & 6.39 & 0.28 & 1.07 \\
\hline IZ-2/28-29 & 60.60 & 10.29 & 32.98 & 0.85 & 23.87 & 94.46 & 45.76 & 133.53 & 8.98 & 0.33 & 0.34 \\
\hline IZ-2/29-30 & 88.56 & 10.50 & 34.08 & 0.85 & 22.99 & 96.61 & 50.34 & 130.88 & 7.38 & 0.27 & 0.20 \\
\hline IZ-2/30-31 & 53.78 & 9.81 & 35.69 & 0.36 & 20.54 & 84.28 & 40.47 & 105.87 & 5.08 & 0.00 & 0.60 \\
\hline IZ-2/31-32 & 55.87 & 7.32 & 34.16 & 0.60 & 23.60 & 106.38 & 45.60 & 141.19 & 0.00 & 0.10 & 0.45 \\
\hline IZ-2/32-33 & 55.57 & 6.01 & 39.70 & 0.55 & 24.86 & 116.69 & 51.03 & 151.56 & 3.35 & 0.00 & 0.44 \\
\hline IZ-2/33-34 & 58.66 & 7.45 & 41.36 & 0.65 & 25.04 & 114.92 & 52.85 & 149.42 & 4.85 & 0.00 & 1.23 \\
\hline IZ-2/34-35 & 55.76 & 7.86 & 41.37 & 0.53 & 22.60 & 106.30 & 47.17 & 132.79 & 5.69 & 0.00 & 0.35 \\
\hline IZ-2/35-36 & 58.55 & 7.97 & 43.93 & 0.13 & 24.62 & 118.57 & 50.55 & 152.08 & 4.90 & 0.00 & 0.62 \\
\hline IZ-2/36-37 & 58.28 & 8.17 & 29.81 & 1.20 & 23.25 & 94.66 & 49.86 & 126.36 & 4.61 & 0.77 & 0.58 \\
\hline IZ-2/37-38 & 54.10 & 5.02 & 35.86 & 0.62 & 22.93 & 112.24 & 47.83 & 147.10 & 2.66 & 0.00 & 1.05 \\
\hline IZ-2/38-39 & 55.04 & 4.85 & 32.50 & 0.86 & 24.14 & 107.91 & 52.36 & 143.25 & 6.26 & 0.40 & 0.75 \\
\hline
\end{tabular}

Table 6. Geochemical analysis results of Group 2 elements of BH-2 drilling ('IZ' is the abbreviation of Iznik, which is the name of an investigation area)

\begin{tabular}{|c|c|c|c|c|c|c|c|c|c|}
\hline SK-2 & $\mathrm{Na}$ & $\mathrm{Mg}$ & K & $\mathrm{Ca}$ & $\mathrm{P}$ & $\mathrm{S}$ & $\mathrm{Fe}$ & $\mathrm{Al}$ & $\mathrm{Mn}$ \\
\hline IZ-2/11-12 & 286.4 & 7886.1 & 2466.5 & 26851.6 & 440.7 & 663.0 & 22430.0 & 9263.6 & 658.3 \\
\hline IZ-2/12-13 & 269.8 & 7937.0 & 2570.1 & 24521.1 & 400.4 & 389.0 & 23500.8 & 9958.2 & 613.7 \\
\hline IZ-2/13-14 & 411.4 & 8412.6 & 3016.2 & 40434.1 & 346.8 & 1037.2 & 22326.5 & 10713.3 & 633.3 \\
\hline IZ-2/14-15 & 443.8 & 10839.5 & 6327.5 & 88874.8 & 395.1 & 444.3 & 30432.4 & 16192.1 & 649.0 \\
\hline IZ-2/15-16 & 436.9 & 10506.2 & 5187.4 & 109611.0 & 387.8 & 473.3 & 28359.4 & 14453.1 & 576.1 \\
\hline IZ-2/16-17 & 394.4 & 10904.9 & 4709.9 & 100292.0 & 455.5 & 449.7 & 31345.1 & 14304.1 & 579.6 \\
\hline IZ-2/17-18 & 409.8 & 11480.9 & 5191.6 & 63810.1 & 464.6 & 374.2 & 35921.3 & 16616.0 & 454.3 \\
\hline IZ-2/18-19 & 463.6 & 9474.2 & 5630.0 & 99791.8 & 385.5 & 540.7 & 26796.5 & 16088.1 & 430.1 \\
\hline IZ-2/19-20 & 372.4 & 10285.3 & 6624.2 & 68235.7 & 408.8 & 339.4 & 31349.5 & 16886.4 & 454.7 \\
\hline IZ-2/20-21 & 365.9 & 10392.0 & 5731.9 & 61303.4 & 558.8 & 380.1 & 35539.7 & 15808.9 & 538.1 \\
\hline IZ-2/21-22 & 381.2 & 10352.7 & 5283.6 & 62259.3 & 434.4 & 344.9 & 29985.3 & 14334.9 & 460.5 \\
\hline IZ-2/22-23 & 403.3 & 10654.7 & 4973.7 & 66137.4 & 519.5 & 471.6 & 30483.4 & 14331.6 & 492.6 \\
\hline IZ-2/23-24 & 474.0 & 13907.4 & 8064.8 & 59099.6 & 464.7 & 690.6 & 35914.9 & 18236.2 & 704.7 \\
\hline IZ-2/24-25 & 697.9 & 11631.2 & 7154.4 & 54365.8 & 543.9 & 1039.5 & 30718.7 & 17912.7 & 527.8 \\
\hline IZ-2/25-26 & 555.8 & 13600.8 & 7781.7 & 55767.6 & 568.4 & 1210.7 & 37301.8 & 18066.4 & 734.2 \\
\hline IZ-2/26-27 & 540.9 & 11788.6 & 7015.7 & 57172.4 & 430.2 & 1147.8 & 31117.5 & 17237.5 & 556.1 \\
\hline IZ-2/27-28 & 589.3 & 12334.8 & 7497.7 & 48340.8 & 465.1 & 1174.6 & 35877.2 & 18245.8 & 680.7 \\
\hline IZ-2/28-29 & 640.8 & 13791.5 & 6421.0 & 45419.9 & 557.5 & 1013.9 & 38820.8 & 17866.3 & 916.4 \\
\hline IZ-2/29-30 & 490.3 & 13684.9 & 6795.8 & 41403.0 & 425.4 & 1772.3 & 39120.4 & 18446.8 & 802.2 \\
\hline IZ-2/30-31 & 500.5 & 12465.0 & 7711.6 & 43510.5 & 375.9 & 3135.9 & 35568.3 & 19101.0 & 659.5 \\
\hline IZ-2/31-32 & 454.2 & 13938.3 & 7279.8 & 38905.5 & 411.0 & 727.7 & 35860.5 & 18451.6 & 823.6 \\
\hline IZ-2/32-33 & 562.1 & 15877.3 & 8694.7 & 43572.3 & 422.8 & 475.3 & 40124.0 & 19566.8 & 872.8 \\
\hline IZ-2/33-34 & 729.3 & 15975.8 & 9237.7 & 45989.6 & 442.8 & 817.2 & 41183.7 & 19751.9 & 941.4 \\
\hline IZ-2/34-35 & 569.6 & 15557.9 & 8944.8 & 45935.8 & 405.2 & 1272.7 & 38724.3 & 19139.0 & 845.9 \\
\hline IZ-2/35-36 & 623.1 & 16498.4 & 9137.2 & 45780.4 & 427.1 & 581.0 & 41424.5 & 19481.5 & 971.9 \\
\hline IZ-2/36-37 & 619.5 & 14814.5 & 6911.4 & 43865.8 & 436.0 & 1246.6 & 40188.4 & 17956.9 & 854.4 \\
\hline IZ-2/37-38 & 598.4 & 16259.3 & 7471.7 & 44514.1 & 392.0 & 487.4 & 36532.4 & 18184.9 & 829.5 \\
\hline IZ-2/38-39 & 552.7 & 15562.4 & 6941.8 & 46022.6 & 415.2 & 662.5 & 39311.0 & 17752.7 & 868.1 \\
\hline
\end{tabular}




\section{References}

1. Meric, E., Nazik, A., Avsar, N., Alpar, B., Unlu, S., \& Gokasan, E. (2009). Evidences of a possible Marmara Sea-Iznik lake connection in Quarternary: determination of ostracods and foraminifers in the recent sediments of the Iznik Lake (Bursa-NW Turkey). Journal of Istanbul Earth Sciences, 22(1), 1-19.

2. Basar, H., Gurel, S., \& Katkat, A. V. (2004). Heavy metal contents of soils soiled by different water sources in Lake Iznik. Journal of Uludag University Agricultural Faculty, 18(1), 93-104.

3. Viehberg, F. A., Damci, E., Ulgen, U. B., Franz, S. O., Roeser, P. A., Wulf, S., Wager, B., Çagatay, M. N., Litt, T., \& Meles, M. (2012). Investigation of Paleo-environmental effects in the Late Pleistocene and Holocene periods at Lake Iznik. In Proceedings of the 65th Geological Congress of Turkey, 2-6 April 2012, Ankara, Turkey, pp. 282-283.

4. UNSCEAR. (2000). United Nations Scientific Committee on the Effects of Atomic Radiation Sources and Effects of Ionizing Radiation, UNSCEAR 2000 Report to the General Assembly, with scientific annexes. Volume I: Sources. New York: United Nations. Available from https://www.unscear.org/unscear/en/ publications/2000_1.html.

5. Degerlier, M. (2007). Determination of environmental natural radioactivity of Adana and surrounding area and finding annual effective dose equivalents of natural radiations. Unpublished Ph.D. Thesis, Cukurova University, Institute of Science and Technology, Department of Physics.

6. Kapdan, E., Taskin, H., Kam, E., Osmanlioglu, A. E., Karahan, G., \& Bozkurt, A. (2011). A study of environmental radioactivity measurements for Cankiri, Turkey. Radiat. Prot. Dosim., 150(3), 398-404.
7. Basar, H., Gurel, S., \& Katkat, A. V. (2009). Metal status of soils and plants irrigated with water from Lake Iznik, Turkey. Commun. Soil Sci. Plant Anal., 40(15/16), 2545-2561.

8. Sagular, E. K., Yumun, Z. U., \& Meric, E. (2018). New didemnid ascidian spicule records calibrated to the nannofossil data chronostratigraphically in the Quaternary marine deposits of Lake Iznik (NW Turkey) and their Paleoenvironmental interpretations. Quat. Int., 486, 143-155.

9. Meric, E., Nazik, A., Yumun, Z. U., Buyukmeric, Y., Avsar, N., Sagular, E. K., Koral, H., \& Gokasan, E. (2018). Fauna and flora of drilling and core data from the Iznik Lake: The Marmara and the Black Sea connection. Quat. Int., 486, 156-184.

10. Yumun, Z. U., \& Kam, E. (2017). Effects of radionuclides on the recent foraminifera from the clastic sediments of the Canakkale Strait-Turkey. J. Afr. Earth Sci., 131, 179-182.

11. Kam, E., \& Bozkurt, A. (2007). Environmental radioactivity measurements in the Kastamonu region of northern Turkey. Appl. Radiat. Isot., 65(4), 440-444.

12. Bozkurt, A., Yorulmaz, N., Kam, E., Karahan, G., \& Osmanlioglu, A. E. (2007). Assessment of environmental radioactivity for Sanliurfa region of southeastern Turkey. Radiat. Meas., 42 (8), 1387-1391.

13. Osmanlioglu, A., Kam, E., \& Bozkurt, A. (2007). Assessment of background radioactivity level for Gaziantep Region of southeastern Turkey. Radiat. Prot. Dosim., 124(4), 407-410.

14. Dede, A. (2014). Evaluation of Iznik Lake water quality parameters with artificial neural networks. Unpublished Master Thesis, Istanbul Technical University, Institute of Science and Technology, Department of Civil Engineering. 